\title{
Evaluation of the effectiveness of environmental disinfection by no touch hydrogen peroxide technology against MDR bacteria contamination and comparison with active chlorine disinfectant
}

\author{
M Ferrari, , A Bocconi, A Anesi \\ From 3rd International Conference on Prevention and Infection Control (ICPIC 2015) \\ Geneva, Switzerland. 16-19 June 2015
}

\section{Introduction}

The multi-resistant organisms (MDRO) survive for long periods of time in a variety of surfaces in hospital environments with high risk of infection trasmission.

\section{Objectives}

The objective of this study was to evaluate effectiveness and non-inferiority of a disinfection system based on $\mathrm{H} 2 \mathrm{O} 2$ and $\mathrm{Ag}+$ micro-mist, vs. chlorine procedure, by monitoring the reduction of microbial contamination on room surfaces.

\section{Methods}

Active chlorine (5.000 ppm), vs. decontamination system based on a solution of $5-8 \% \mathrm{H} 2 \mathrm{O} 2$ and $60 \mathrm{ppm}$ active $\mathrm{Ag}+\left(1 \mathrm{~mL} / \mathrm{m}^{3}\right.$ intensity of treatment) were compared. Two beds 26 rooms located in different wards mainly within the Departments of Medicine and Rehabilitation were previously occupied by patients infected by MDRO. Environment and medical equipment disinfection procedures were performed prior to a new bed occupancy in addition to routine cleaning activities. 10 surfaces were sampled in the hospital room. Microbial colonisation was assessed at Time 0 (T0) before cleaning, $\mathrm{T} 1$ immediately after cleaning and $\mathrm{T} 2$ after disinfection procedures, using swabs on a surface area of approximately $57 \mathrm{~cm}^{2}$. All swabs were inoculated with standard procedure and evaluated on CFU per $\mathrm{cm}^{2}$. Organisms were identified by standard microbiological methods.

\footnotetext{
City Hospital Lodi, Lodi, Italy
} Attribution License (http://creativecommons.org/licenses/by/4.0), which permits unrestricted use, distribution, and reproduction in any medium, provided the original work is properly cited. The Creative Commons Public Domain Dedication waiver (http:// creativecommons.org/publicdomain/zero/1.0//) applies to the data made available in this article, unless otherwise stated. 